\title{
Effects of Hydrocortisone on Peritoneal Free Cells in Mice
}

\author{
Sato Honma, Kazuhiro AвE and Takashi Ito \\ Department of Anatomy (Prof. T. ITo), Hokkaido University School of Medicine, Sapporo, Japan
}

Received October 30, 1980

Summary. Eff ects of hydrocortisone on peritoneal free cells in the mouse were examined by quantitative morphologic procedures.

Mice of both sexes at 60 to 65 days of age received one, two, or four successive subcutaneous injections of $0.5 \mathrm{mg}$ hydrocortisone every $24 \mathrm{hrs}$. After one injection, peritoneal free cells showed a rapid decrease in number during the first $3 \mathrm{hrs}$. They then increased up to about 1.5 times the control value at $24 \mathrm{hrs}$ and returned to the normal level at $48 \mathrm{hrs}$ in both sexes. After two injections, peritoneal cells showed a significant decrease in number in females during the first 2 days. Thereafter they returned to normal in both sexes at 8 to 12 days.

The three major types of peritoneal cells, type I, II and III cells, which have been described in pervious papers (ABE et al., 1979a, b; HONMA et al., 1980), differed in response to hydrocortisone. Type I cells (small lymphocytes) were markedly reduced in number immediately after hydrocortisone injection and remained depleted even 12 days after injection. Type II cells (medium-sized mononuclear cells) showed the most remarkable response to hydrocortisone. Changes in the total number of peritoneal cells following hydrocortisone injection were ascribed mainly to those of type II cells. Type III cells (macrophages) did not show any significant changes in number after injection.

Glucocorticoids are known to exert intensive effects on lymphatic tissues (Dougherty, 1952; Ito and Hoshino, 1962; Esteban, 1968) and monocytes (Thompson and van Furth, 1973; Fauci, 1979). Effects of glucocorticoids on peritoneal cells were observed in mice by THOMPSON and VAN FurTh (1970), who focused special attention on macrophages and lymphocytes. As reported in our previous papers (ABE et al., 1979a, b; Honma et al., 1980), however, peritoneal cells in mice are composed of three major types, termed type I, II and III cells. Type I cells are small lymphocytes and type III cells are macrophages. Type II cells are medium-sized mononuclear cells which are distinguishable from the other two types of cells. Therefore each of the three types of cells should be examined when peritoneal cells are experimentally dealt with. In addition, a sex difference should be taken into consideration, because in adult mice there are almost twice as many peritoneal cells in females as in males (ABE et al., 1979b; Honma et al., 1980). For these reasons this study was undertaken to examine whether or how peritoneal cells are affected by hydrocortisone with particular consideration to the three peritoneal cell types and sexes. 


\section{MATERIALS AND METHODS}

A total of 214 dd-mice of both sexes which were maintained with commercial mouse pellet diets (NMF, Oriental Co., Tokyo) and water ad libitum in constant environmental conditions were used. At 60 to 65 days of age, hydrocortisone acetate (Scheroson F, Schering), $0.5 \mathrm{mg}$ in $0.2 \mathrm{ml}$ saline, was injected subcutaneously in the nuchal region. For each mouse, one, two, or four successive injections were given every 24 hrs. Mice of both sexes of the same age which were used in the previous study (Honma et al., 1980) served as the control. The mice were killed with chloroform at various intervals after injection.

Peritoneal free cells were obtained with $10 \%$ formalin in $0.1 \mathrm{M}$ phosphate buffer $(\mathrm{pH}$ 7.5) injected directly into the peritoneal cavity. The total number and size distribution curves of the peritoneal cells were obtained by Coulter counter and channelyzer (Model ZBI) in the same procedure as previously described in detail (ABE et al., 1979b; Honma et al., 1980).

For light microscopic analysis, smears of the peritoneal aspirates were stained with periodic acid-Shiff reagent (PAS) and hematoxylin. The differential cell counts were performed in 500 cells in smears for each case, as described previously (HonmA et al., 1980).

The statistic significance of the results obtained was evaluated by Student's $t$-test.

\section{RESULTS}

Total number of peritoneal cells: The total number of peritoneal cells in the control is $6.96 \pm 0.36\left(\times 10^{6}\right)$ in males and $11.57 \pm 0.57\left(\times 10^{6}\right)$ in females. Thus a significant sex difference is present in the number of peritoneal cells.

In mice treated with a single injection of hydrocortisone, as shown in Figure 1a, peritoneal cells rapidly decreased in number immediately after injection. The effect was maximal $3 \mathrm{hrs}$ after injection in males and $6 \mathrm{hrs}$ in females. Peritoneal cells then increased again and showed about a $50 \%$ increase of the control value in males and a $30 \%$ increase in females 24 hrs after injection. The total number of peritoneal cells was almost at the normal level 48 hrs after injection.

In the mice which had received the second injection $24 \mathrm{hrs}$ after the first one (Fig. 1b), the number of peritoneal cells was at the normal level in males, whereas it underwent a 30 to $40 \%$ decrease in females during the first 2 days. Thus peritoneal cells showed no sex difference in number. Then they gradually increased in number in the females, whereas they remained almost unchanged in the males. Thus a sex difference was again apparent in the cell number from the 4th day onward.

In the mice treated with four consecutive injections, peritoneal cells showed a considerable decrease in number in both sexes $24 \mathrm{hrs}$ after the last injection (Fig. 1c).

Number of the three types of peritoneal cells: Distribution curves of the cell volume obtained by Coulter counter and channelyzer are shown in Figure 2. The curves of the control have three peaks in both sexes. The peaks correspond to the frequencies 


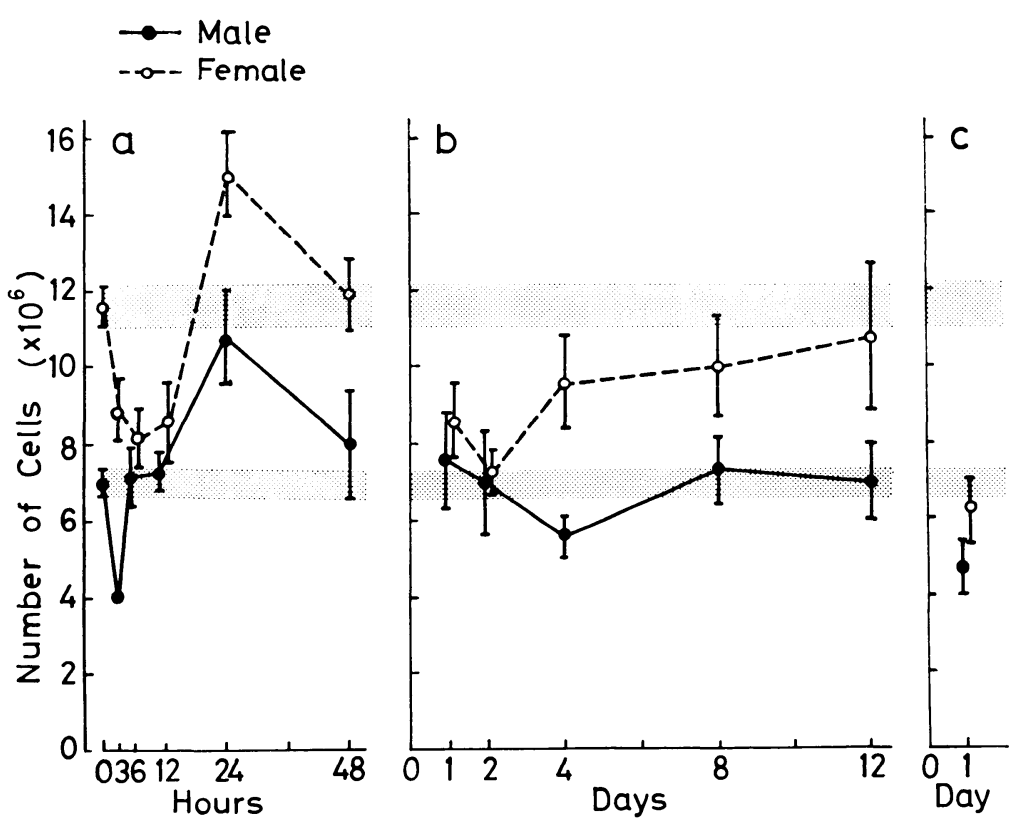

Fig. 1. Total number of peritoneal cells after one (a), two (b) or four (c) injections of hydrocortisone. The abscissa represents the time after the last injection. Stippled bands represent ranges of standard errors of the control values in male and female. Bars show standard errors.

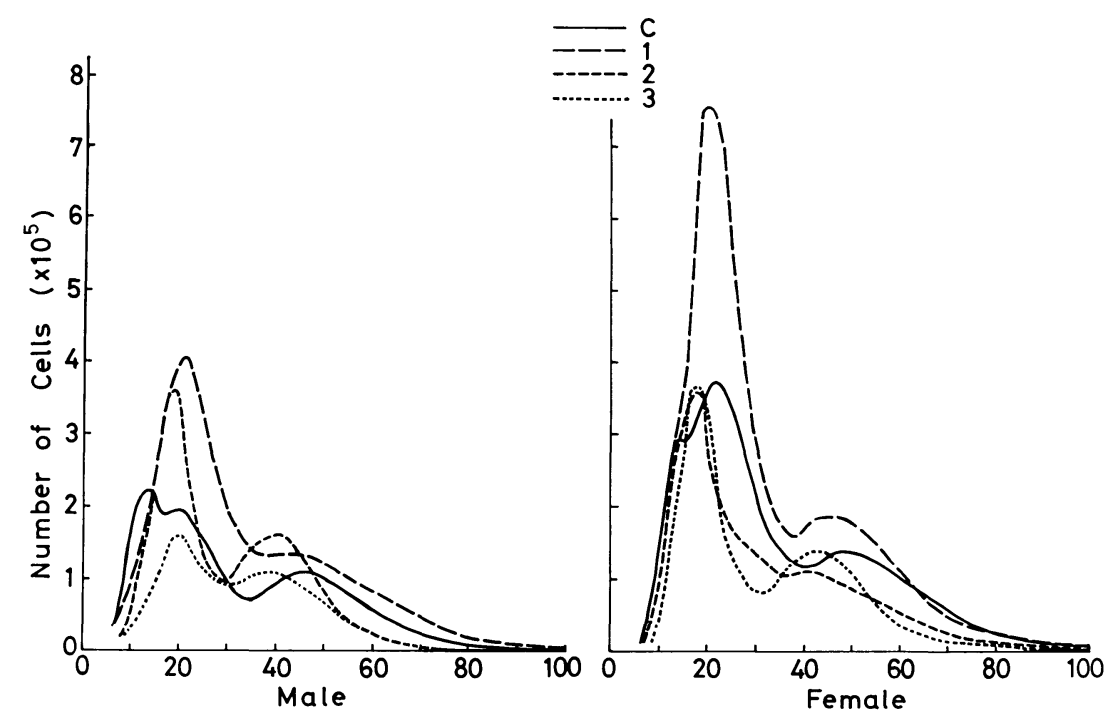

Fig. 2. Size distribution curves of peritoneal cells of the control (C), and at 24 hs after the last injection of one (1), two (2) or four (3) injections of hydrocortisone. Each curve represents the average of each group. The abscissa represents the relative volume of cells. 
of the three types of peritoneal cells which were designated type I (small lymphocytes), II (medium-sized mononuclear cells) and III (macrophages) in our previous paper (ABE et al., 1979b). The population size of each type representing each peak can be estimated from the area occupied in the curve.

In mice treated with a single injection of hydrocortisone, the peak which represents the frequency of type I cells is no longer apparent, presumably because type I cells are too small in number to form a separate peak. The frequency of type II cells shows a striking increase especially in females. The peak formed by type III cells is also elevated slightly in height.

In mice treated with two injections, the peak which represents type II cells is similar in height to the control curve but very steep and shifted toward the left. This finding indicates that type II cells decrease in number and volume as compared with those in untreated controls. The peak formed by type III cells also shows a slight shift toward the left.

The curves obtained from mice receiving four injections are essentially the same in pattern as those from mice treated with two injections.

The number of each type of peritoneal cells in mice treated with hydrocortisone is shown in Figure 3, 5 and 6 . In mice treated with a single injection, as seen in Figure 3, type I cells (small lymphocytes) decreased to about a half of those of the controls. Degenerated small lymphocytes were frequently seen in smears of peritoneal cells harvested 6 to $24 \mathrm{hrs}$ after injection. They were most frequent $12 \mathrm{hrs}$ after injection. They were usually adhered to or occasionally phagocytosed by macrophages (type III cells). Two to seven macrophages surrounded and adhered to
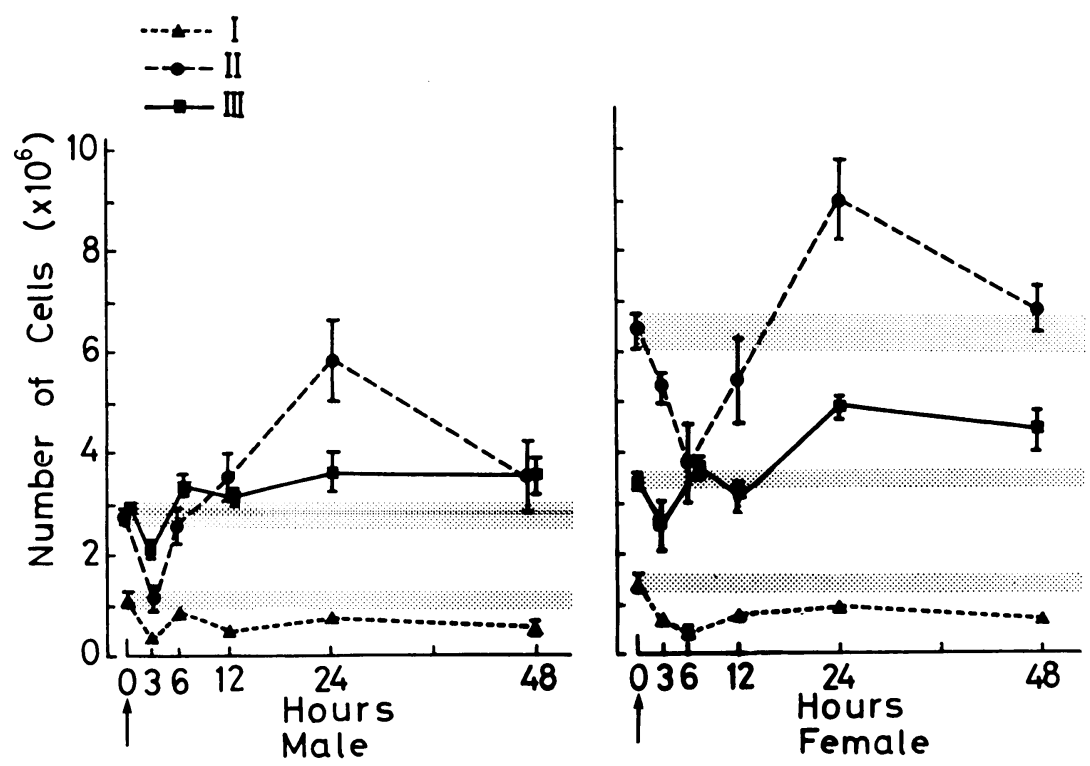

Fig. 3. Mumber of type I, II and III cells after one injection of hydrocortisone (arrows). The abscissa represents the time after the injection. Stippled bands represent ranges of standard errors of the control value. Bars show standard errors. 
one degenerated lymphocyte with piknotic nucleus or sometimes cell debris (Fig. 4). Type II cells (medium-sized mononuclear cells) underwent a significant change in number following injection. They decreased markedly at first, but then increased strikingly until at $24 \mathrm{hrs}$, they were more numerous than in the controls. Thereafter, type II cells decreased again, and they were almost within a normal range in

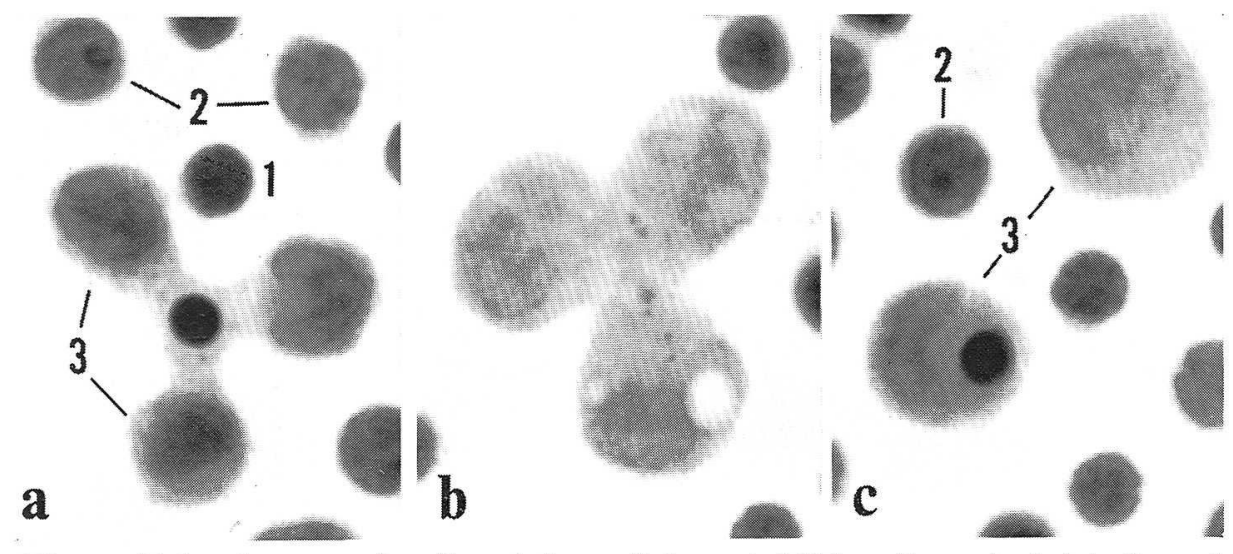

Fig. 4. Light microscopy of peritoneal free cells harvested $12 \mathrm{hrs}$ after a single injection. 1 type I cell, 2 type II cell, 3 type III cell. a. Three macrophages (type III cells) adhere to a degenerated small lymphocyte (type I cell). b. Three macrophages adhere to cell debris. c. A degenerated lymphocyte is phagocytosed by a macrophage.
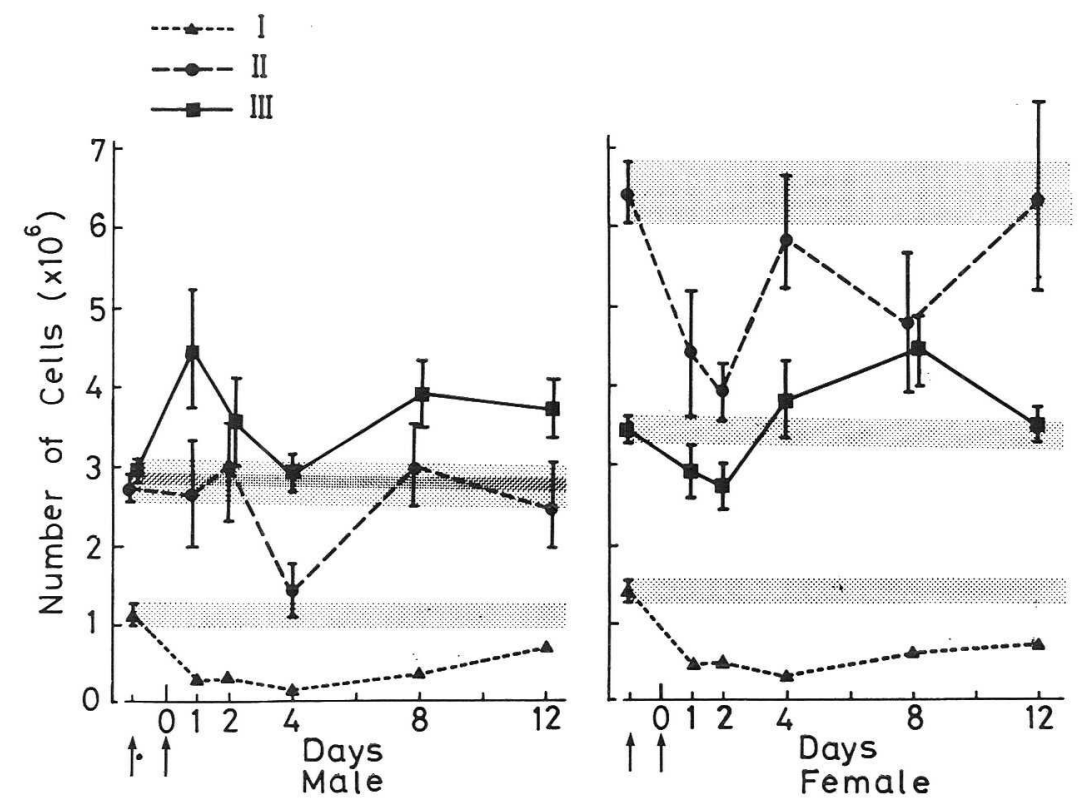

Fig. 5. Number of type I, II and III cells after two injections of hydrocortisone (arrows). The abscissa represents the time after the second injection. Stippled bands represent ranges of standard errors of the control values. Bars show standard errors. 


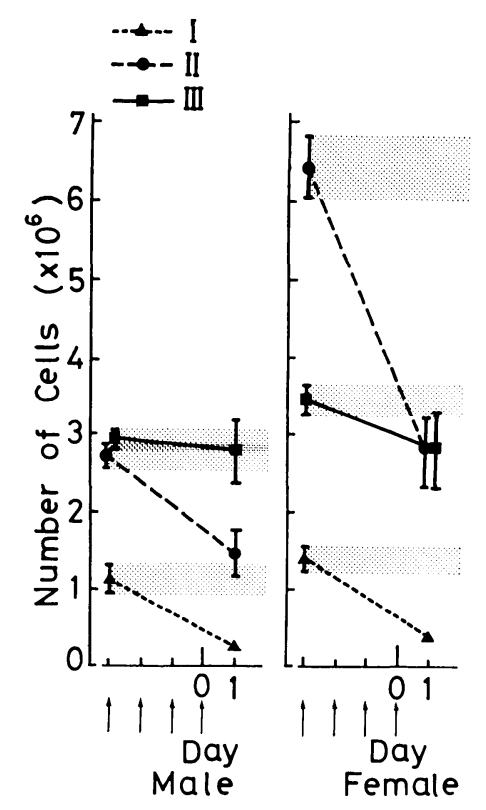

Fig. 6. Number of type I,II and III cells after four injections of hydrocortisone (arrows). The abscissa represents the time after the last injection. Stippled bands represent ranges of standard errors of the control values. Bars show standard errors. number 48 hrs after injection. Type III cells (macrophages) were not significantly changed in number after a single injection, although they showed a significant increase $24 \mathrm{hrs}$ after injection only in females.

In mice treated with two injections, as seen in Figure 5, type I cells remained depleted as has been thus far examined, although they tended to be gradually restored after 8 days. Type II cells showed more marked changes in females than in males. In males, they remained less changed in number, although they showed a decrease only 4 days after the second injection. In females, on the other hand, type II cells showed a significant decrease in number especially during the first two days after injection. Thus, no significant sex difference was seen in the number of type II cells early after injection. In females, however, type II cells then increased in number. Thus, they were more numerous in females than in males after 4 days. Type III cells exhibited a slight increase in number $24 \mathrm{hrs}$ after injection. Otherwise, no significant change was seen in the number of type III cells for either sex according to current examinations.

In mice treated with four injections, type I and II cells became almost a quarter and a half in number, respectively, while type III cells showed almost no changes in number $24 \mathrm{hrs}$ after the last injection (Fig. 6).

\section{DISCUSSION}

After a single injection of hydrocortisone, the total number of peritoneal free cells showed a rapid and marked decrease which was immediately followed by a marked rebounding increase. Thus, peritoneal cells have returned to baseline in number $48 \mathrm{hrs}$ after injection. The rebound in number may occur only following administration of a certain dose of hydrocortisone, because it has not been noted in mice treated with higher doses of hydrocortisone (THOMPSON and VAN FURTH, 1970). As shown in the results, the initial remarkable change in the number of peritoneal cells is attributed mainly to that in type II cells.

In mice treated with one injection of hydrocortisone, peritoneal cells showed essentially similar changes in total number between the two sexes. After two injections, type II cells decreased in number more markedly in females than in males. Thus no sex difference was apparent in the total number during the first two days after injection. As reported previously, a significant sex difference in the total 
number of peritoneal cells in normal adults is ascribed mainly to that in type II cells, and it is caused primarily by a suppressive effect of the testicular hormone (Honma et al., 1980). The response of peritoneal cells to hydrocortisone also varies to some extent depending on the sex, and the sex difference is largely attributed to that in type II cells.

It has long been known that corticosteroids exert striking effects on lymphocytes (Dougherty, 1952; Dougherty et al., 1964; Esteban, 1968; Cohen, 1972). As shown in the present results, hydrocortisone causes a depletion of peritoneal lymphocytes (type I cells). The depletion is, at least in part, due to lymphocytolysis, because degenerated lymphocytes were often seen in the specimens harvested 6 to 24 hrs after a single injection of hydrocortisone. These degenerated lymphocytes seemed to be digested by macrophages (type III cells). Two to seven macrophages adhered to one dead lymphocyte with pyknotic nucleus or sometimes cell debris. Thus, it is suggested that these macrophages digest degenerated lymphocytes extracellularly without phagocytosing them.

Peritoneal lymphocytes were not totally depleted even by consecutive injections of hydrocortiosone. About a quarter of the peritoneal lymphocytes were hydrocortisoneresistant and remained in the peritoneal cavity even after four injections (Fig. 6). Therefore, small lymphocytes contained in the mouse peritoneal cavity are thought to be composed of at least two subpopulations which differ in sensitivity to hydrocortisone. It is generally accepted that lymphocytes consist of two subpopulations which are different in sensitivity to glucocorticoids (Claman, 1972; Greaves et al., 1973; AвE and Ito, 1978; FAuci et al., 1980). Gillette et al. (1973) noted that peritoneal lymphocytes represent a specialized subpopulation of lymphocytes that are functionally different from those in the spleen or lymph node. CATANZARO (1974a, b) reported that peritoneal lymphocytes represent a T-cell-poor population which consists of a large number of B-cells. Thus, peritoneal lymphocytes depleted following hydrocortisone injection may be B-lymphocytes which are known to be sensitive to glucocorticoids.

Type II cells, as seen in the results, undergo a profound decrease in number soon after a single injection of hydrocortisone, but they later increase and return to baseline. Such initial depletion and then rebounding increase of type II cells during a short period suggest that there may be a large pool from which type II cells can readily transit into the peritoneal cavity. In this relation, milky spots have been considered to serve as a nest of macrophages (Mixter, 1941; Felix, 1961; CARR, 1967) though there is some evidence that peritoneal cells may ultimately originate from bone marrow (Balner, 1963; Goodman, 1964; van Furth, 1976). Takemori (1979) has recently reported that omental milky spots consist of not only macrophages but of two other types of cells which are similar in appearance to type I and II cells of peritoneal free cells. It is also reported that omental milky spots in mice contain no $\mathrm{T}$ lymphocytes (Szaniawska, 1975). This finding suggests that lymphoid cells in omental milky spots are functionally similar to peritoneal lymphocytes. Thus, type II cells as well as the other two types of peritoneal cells may be readily derived from omental milky spots. It has been reported that a transient depletion followed by a rebounding increase of blood monocytes is caused by dexamethasone in the mouse (Thompson and VAN Furth, 1970) and in man (PARILlo and FAUCI, 1978) and it is considered to be due to the sequestration and recruitment of the circulating monocytes 
in a compartment of unknown localization. On the other hand, it has been noted that prolonged monocytopenia is caused by hydrocortisone administered subcutaneously in the mouse (Thompson and VAN FURTH, 1970,1973). There is no evidence to indicate that blood monocytes transform immediately into type II cells in the peritoneal cavity. As demonstrated in our previoue papers type II cells are peroxidase negative and morphologically distinguishable from monocytes (ABE et al., 1979a, b). In any case, further studies are required to elucidate the origin, kinetics and nature of type II cells.

Glucocorticoids are known to exert an intensive effect on the monocyte-macrophage system (Rosenthal and Balow, 1975; Fauci, 1979). Monocytes, either circulating (Thompson and van Furth, 1970; Leibovich and Ross, 1975) or cultured (Werb, 1978; Hamilton et al., 1976), are sensitive to glucocorticoids. On the other hand, tissue macrophages show no decrease in number after the administration of glucocorticoids (Thompson and VAN FurTh, 1970; Domby and Whitcomb, 1978), because they are rather resistant to corticoids and have a long turnover time (VAN FURTH, 1976; Crofton et al., 1978; van oud Alblas and van Furth, 1979). It has also been reported that hydrocortisone causes little change in the number of peritoneal macrophages (ThOMPSON and VAN FURTH, 1970). The present finding that type III cells (macrophages) undergo no significant change in number after hydrocortisone injection is essentially in accord with the previous findings of THOMPSON and VAN FURTH (1970).

\section{マウス腹膜腔自由細胞に及ぼすハイドロコーチゾンの影響}

本間さと, 阿部和厚, 伊藤隆

マウス腹膜腔の自由細胞に対する ハイドロコーチゾンの影響を 定量形態学的に検索した.

60〜65日齢の䧳雄 dd-マウスに，八イドロコーチゾン $0.5 \mathrm{mg}$ を 1 回 または24 㭙問ご とに 2 回および 4 回 背部皮下に注射し, 腹膜腔細胞を経時的に採種し, その総数と細胞 別構成をコールターカウンターと光学顕微鏡的観察によって求めた.

ハイドロコーチゾン 1 回注射後 3 㭙閂で 細胞総数は急速に減少するが，その後 再び増 加し，24封間後には 対照群の約 1.5 倍の值となる. 2 回投与では，注射後 $1 \sim 2$ 日で, 雄は正常マウスとほぼ同值を示すが，此では有意に減少し，細胞数に性差はみられなくな る. 2 回投与後 8 日以降では 雌雄とも正常レベルを示す.

腹膜腔自由細胞は おもに I 型 (小リンパ球)， II 型 (中型単核細胞)， III型（大食細胞） の 3 型の細胞によって構成される (ABE et al., 1979a, b; Honma et al., 1980). ハイドロコ ーチゾンを投与するとI型は急速に減少し，2 回注射後 12 日でも低值を示す。II 型は著 明な変動を示し， 1 回投与後 $3 \sim 6$ 時間で雌雄とも正常値の約1反に減少し，ついで急速に 増加して 24 時間後には正常値の 2 倍近い高值となり，48時間後にほぼ正常值に復する. また 2 回投与では，1〜2 日後に雄は正常レベルを示すが，雌では低值となり，細胞数 に性差はみられない。 III型はハイドロコーチゾン投与により著変を示さない。 


\section{REFERENCES}

Abe, K., S. Honma and T. Ito: Response of peritoneal cells to horseradish peroxidase and aldehyde-fixed erythrocytes in the mouse: An electron microscope study. Arch. histol. jap. 42: 263-276 (1979a). phology. Amer. J. Anat. 156: 37-50 (1979b).

Abe, K. and T. Ito: Qualitative and quantitative morphologic study of Peyer's patches of the mouse after neonatal thymectomy and hydrocortisone injection. Amer. J. Anat. 151: 227-238 (1978).

Balner, H.: Identification of peritoneal macrophages in mouse radiation chimeras. Transplantation 1: 217-223 (1963).

Carr, I.: The fine structure of the mouse peritoneum. Z. Zellforsch. 80: 534-555 (1967).

Catanzaro, P. J., R. C. Graham and C. P. Burns: Mouse peritoneal lymphocytes: General properties of normal peritoneal lymphocytes. J. Reticuloendothel. Soc. 16: 150-160 (1974a).

Catanzaro, P. J., R. C. Graham and W. R. Hogrefe: Mouse peritoneal lymphocytes: A morphologic comparison of normal and exsudate peritoneal lymphocytes. J. Reticuloendothel. Soc. 16: 161-174 (1974b).

Claman, H. N.: Corticosteroids and lymphoid cells. N. Engl. J. Med. 287: 388-397 (1972).

Cohen, J. J. : Thymus-drived lymphocyte sequestered in the bone marrow of hydrocortisone-treated mice. J. Immunol. 108: 841-844 (1972).

Crofton, R. W., M. M. C. Diesselhoff-den Dulk and R. van Furth : The origin, kinetics, and characteristics of the Kupffer cells in the normal steady state. J. exp. Med. 148: 1-17 (1978).

Domby, W. R. and M. E. Whitcomb : The effects of corticosteroid administration on the bronchoalveolar cells obtained from guinea pigs by lung lavage. Amer. Rev. Respir. Dis. 117: 893-896 (1978).

Dougherty, T. F.: Effects of hormones on lymphatic tissue. Physiol. Rev. 32: 379-401 (1952).

Dougherty, T. F., M. L. Berliner and G. L. Schneebeli : Hormonal control of lymphatic structure and function. Ann. New York Acad. Sci. 113: 825-843 (1964).

Esteban, J. N.: The differential effect of hydrocortisone on the short-lived small lymphocyte. Anat. Rec. 162: 349-356 (1968).

Fauci, A. S.: Glucocorticoid effects on circulating human mononuclear cells. J. Reticuloendothel. Soc. 26: 727-738 (1979).

Fauci, A. S., T. Murakami, D. D. Brandon, D. L. Loriaux and M. B. Lipsett : Mechanisms of corticosteroid action on lymphocyte subpopulations. VI. Lack of correlation between glucocorticosteroid receptor and the differential effects of glucocorticosteroids on T-cell subpopulations. Cell. Immunol. 49: 43-50 (1980).

Felix, M. D.: Observations on the surface cells of the mouse omentum as studied with the phasecontrast and electron microscopes. J. Nat. Cancer Inst. 27: 713-745: (1961).

Gillette, R. W., C. W. Boone and M. H. Swanson: Unique homing properties of nonadherent peritoneal cells. Cell. Immunol. 9: 445-452 (1973).

Goodman, J. W.: On the origin of peritoneal fluid cells. Blood 23: 18-26 (1964).

Greaves, M. F., J. J. T. Owen and M. C. Raff : T and B lymphocytes: origin, properties and roles in immune responses. Excerpta Medica, American Elsevier, Amsterdam-London. 1973.

Hamilton, J., J.-D. Vassalli and E. Reich: Macrophage plasminogen activator: Induction by asbestos is blocked by anti-inflamatory steroids. J. exp. Med. 144: 1689-1694 (1976).

Honma, S., K. Abe and T. Ito: Age- and sex-related changes of peritoneal free cells in mice: Quantitative morphologic study. Arch. histol. jap. 43: 127-139 (1980).

Ito, T. and T. Hoshino: Histological changes of the mouse thymus during involution and regeneration following administration of hydrocortisone. Z. Zellforsch. 56: 445-464 (1962). 
Leibovich, S. J. and R. Ross: The role of the macrophages in wound repair. A study with hydrocortisone and antimacrophage serum. Amer. J. Pathol. 78: 71-100 (1975).

Mixter, R. L.: On macrophagal foci ("milky spots") in the pleura of different mammals, including man. Amer. J. Anat. 69: 159-186 (1941).

Parrillo, J. E. and A. S. Fauci : Mechanisms of corticosteroid action on lymphocyte subpopulations III. Differential effects of dexamethasone administration on subpopulations of effector cells mediating cellular cytotoxicity in man. Clin. exp. Immunol. 31: 116-125 (1978).

Rosenthal, A. S. and J. E. Balow : Mechanisms of glucocorticosteroid suppression of cell-mediated immunity. In: (ed. by) R. van Furth: Mononuclear phagocytes, in immunity, infection and pathology. Blackwell, Oxford, 1975. (p. 701-710).

Szaniawska, B.: Changes in the greater omentum of mice of different strains following intraperitoneal immunization with sheep erythrocytes. III. Determination of the percentage of thymus-dependent cells in the omental milky spots in mice by the application of anti- $\theta$ serum. Arch. Immunol. Ther. Exp. 23: 19-24 (1975).

Takemori, N.: Morphological studies of the omental milk spots in the mouse: Light and electron microscopy. Hokkaido J. med Sci. 54: 265-283 (1979).

Thompson, J. and R. van Furth: The effect of glucocorticoids on the kinetics of mononuclear phagocytes. J. exp. Med. 131: 429-442 (1970).

: The effect of glucocorticosteroids on the proliferation and kinetics of promonocytes and monocytes of the bone marrow. J. exp. Med. 137: 10-21 (1973).

van Furth, R.: Origin and kinetics of mononuclear phagocytes. Ann. New Yorh Acad. Sci. 278: 161-175 (1976).

van oud Alblas, A. B. and R. van Furth: Origin, kinetics and characteristics of pulmonary macrophages in the normal steady state. J. exp. Med. 149: 1504-1518 (1979).

Werb, Z. : Biochemical actions of glucocorticoids on macrophages in culture. Specific inhibition of elastase, collagenase, and plasminogen activator secretion and effects on other metabolic functions. J. exp. Med. 147: 1695-1712 (1978).

\section{阿部和厚}

$\overline{\mathbf{T}} 060$ 札幙市北区北15条西 7 丁口

北海道大学医学部

解剖学第三講座
Dr. Kazuhiro AвE

Department of Anatomy

Hokkaido University School of Medicine

Sapporo, 060 Japan 